\title{
COViD-19 Sürecinde Çocukların Oyun Bağımlılığı Düzeylerinin Uyku ve Akademik Başarılarına Etkisi
}

\section{Effect of Children's Game Addiction Levels on Sleep and Academic Achievement in the COVID-19 Process}

\author{
Yeliz Suna Dağ ${ }^{1}$ (D), Yakup Ömür Yayan 2 ${ }^{\text {ID }}$, Emriye Hilal Yayan ${ }^{1}$ (DD \\ 1. Inönü Üniversitesi, Hemşirelik Fakültesi, Malatya \\ 2. Doğanyol İlkokulu, Doğanyol, Malatya
}

\begin{abstract}
Objective: The aim of this study is to examine the effects of children's game addiction levels on their sleep and academic success.

Method: The study was conducted with 123 parents and children. In the study,'Digital Game Addiction Scale for Children' and 'Children's Sleep Habits Questionnaire'.

Results: $52 \%$ of the children included in the study were girls, the average age was $10.21 \pm 1.30$ and their academic achievement was mostly good. $92 \%$ of the children were in the risk group for digital game addiction and all of them had sleep problems. The availability of a computer/tablet at home, the time children spend on the computer/tablet and being allowed to spend time on the computer/tablet affect children's sleep. There was a positive correlation between the children's academic achievement and their sleep time while there was a negative correlation between children's academic achievement and the total score and subscales of game addiction. In addition, the digital game addiction scale and its subscales positively affected the total scores of sleep anxiety, night awakenings, parasomnia, daytime sleepiness and sleep scale.

Conclusion: Children were in the risk group for digital game addiction and had sleep problems. In this direction, it is recommended to provide education and counseling according to the technology use and sleep needs of children. Keywords: Child, sleep, digital game addiction, academic achievement

Öz

Amaç: Bu araştırma çocukların oyun bağımllı̆̆ı düzeylerinin uyku ve akademik başarılarına etkisini incelemek amaci ile yapıldı.

Yöntem: Araştırma 123 ebeveyn ve çocukla yapıldı. Araştırmada 'Ebeveyn ve Çocuk Bilgi Formu' Çocuklar İcin Dijital Oyun Bağımlığı Ölçeği' ve 'Çocuk Uyku Alışkanlıkları Anketi' kullanıldı.

Bulgular: Çalışma kapsamına alınan çocukların \%52'sinin kız, yaş ortalamalarının 10.21 1.30 ve çoğunlukla akademik başarılarının iyi olduğu saptanmıştır. Çocukların \%92'sinin dijital oyun bağımlı̆̆ğı için riskli grupta oldukları ve tamamının uyku sorunu yaşadığı bulunmuştur. Evde bilgisayar/tablet bulunması, çocukların bilgisayar/tablette geçirdikleri süre ve bilgisayar/tablette zaman geçirmelerine izin verilme durumlarının çocukların uykularını etkilediği belirlenmiş̧tir. Çocukların akademik başarılarının uyku süreleri ile aralarında pozitif ilişki ve oyun bağımlıı̆ı toplam puanı ve alt boyutları ile negatif ilişki olduğu tespit edilmiş̧tir. Ayrıca dijital oyun bağımlılığı ölçeği ve alt boyutlarının uyku kaygısı, gece uyanmaları, parasomnia, gün içinde uykululuk ve uyku ölçeği toplam puanlarını pozitif yönde etkilediği belirlenmiştir.

Sonuç: Araştırmamızda çocukların dijital oyun bağımlıı̆ı için riskli grupta oldukları ve uyku sorunu yaşadıkları belirlenmiştir. Bu doğrultuda çocukların teknoloji kullanımları ile uyku gereksinimlerine göre eğitim ve danışmanlık verilmesi önerilmektedir.

Anahtar kelimeler: Çocuk, uyku, dijital oyun bağımlıı̆ı, akademik başarı




\section{Giriş}

Bilişim teknolojilerindeki gelişmeler günlük hayatımııı her alanında değişikliklere neden olmuş ve yaşamımızın önemli bir parçası haline gelmiştir(1-3). Günümüzde teknolojideki hızlı ilerlemelerle beraber kentleşme ve oyun alanlarının yetersizliği gibi nedenlerle, bireylerdeki oyun algısı değişmiş ve geleneksel oyun etkinliklerinin yerini dijital oyunlar almıştır $(2,4,5)$. Dijital oyunlar, hemen her yaşta bireylerin başvurduğu serbest zaman geçirmek, stres atmak, eğlenmek gibi amaçlarla kullanılan aktivitelerdir. İlgili alanda 10- 19 yaş arası çocukların dijital oyunlara yoğun ilgi gösterdikleri ve bu oyunlarla geçirilen zamanın sürekli arttığı belirlenmiştir $(6,7)$. Hazar'a göre dijital oyunlar, özellikle çocuk ve gençler için eğlence ve boş zaman anlayışının önemli bir parçası haline gelmiş ve temel yaşam aktivitelerinden biri olmuştur (8). Çocukların dijital oyunlardan kolay etkilenebildiği ve bu oyunların çocukların bilişsel duygusal ve sosyal yönden birçok olumlu ve olumsuz etkilerinin olduğu belirtilmiştir (9) .

Yapılan bazı çalışmalarda dijital oyunların çocuklarda görsel zekayı geliştirdiği, ders başarısına katkı sağladığı, eğlenceli vakit geçirerek stresini azalttığı, özgüvenini arttırdığı $(2,3,10)$, bilişsel gelişimlerine katkı sağladığı, problem çözme becerisini geliştirdiği belirlenmiştir $(9,11,12)$. Ancak farklı çalışmalarda dijital oyunların çocuklarda yalnızlık, depresyon, anksiyete, şiddet eğiliminde artış ve iletişim sorunları gibi psikososyal ve davranışsal sorunlarla beraber çocukların öz bakım yetersizliği, yetersiz/düzensiz uyku ve beslenme alışkanlığı, hareketsizliğe bağlı dolaşım, solunum kas iskelet sistemi sorunları yaşadıkları belirtilmişstir $(5,13,14)$. Son bir yıldır yaşadığımız pandemi sürecinde birçok kısıtlamayla beraber iletişim teknolojileri ve internet kullanımı tüm dünyada olduğu gibi ülkemizde de yoğun bir şekilde artmıştır (15). Pandemide internet kullanımı, eğitim ve kurum faaliyetlerinin sürdürülmesi, bireylerin birbirleriyle iletişim kurabilmesi ve birçok sosyal aktivitenin gerçekleştirebilmesi açısından hayatı kolaylaştırmıştır (16). Ancak ilgili alanda pandemi öncesine oranla bireylerin yaşadıkları kaygıyı azaltabilmek için sosyal medya kullanma, internette gezinme ya da dijital oyun oynama gibi bağımlılık riski taşıyan davranışlara daha fazla yönelebildiği bildirilmiştir $(17,18)$.

Ayrıca pandemi sürecinde eğitim faaliyetlerinin uzaktan eğitimle sağlanması, evde geçirilen zamanın artması, okul ve arkadaş ortamlarından uzaklaşma gibi durumların çocukların dijital ortamlara katılım oranını arttırdığı ifade edilmiştir (19-21). Konu ile ilgili olarak ilgili alanda pandemi sürecinde çocukların oyun bağımlııklarını ve etkilerini inceleyen çalışmaya rastlanılmadığı görülmektedir. Bu doğrultuda araştırmamız Covid-19 sürecinde çocukların oyun bağımlııklarının uyku ve akademik başarılarına etkisini incelemek amacıyla yapıımıştır. Bu araştırmada; Covid-19 sürecinde çocukların oyun bağımlılık oranları ne düzeydedir? Covid-19 sürecinde çocukların oyun bağımlıık düzeyleri ve uykuları ilişkili midir? Covid-19 sürecinde çocukların oyun bağımlılıklarının akademik başarılarına etkisi var mıdır? Sorularına yanıt aranmıştır.

\section{Yöntem}

\section{Örneklem}

Araştırmanın evrenini 1 Ocak 2020-31 Mayıs 2020 tarihleri arasında İstanbul'da bir okuldaki ilköğretim öğrencileri oluşturmuştur. İstanbul'un çok kültürlü bir bölge olması nedeniyle araştırmamızda amaçlı örnekleme yöntemi kullanılmıştır. Örneklem seçiminde benzer kültürel özellik taşıması amacıyla bir bölgedeki tek bir okul seçilmiştir. Seçilen okulun 3. ve 4. sınıf 200 öğrencisi bulunmaktadır. Araştırmamızda örneklem seçimine gidilmemiş tüm 3.ve 4. sınıf öğrencileri ve ebeveynleri örnekleme alınmıştır. Evrenin tamamına ulaşılması hedeflenmiş ve öğrenciler ve ebeveynlerin tamamı ile görüşme sağlanmıştır. Çalışmaya katımayı kabul ederek görüşme sonrası dönüş yapan, okuduğunu anlayabilen ve sorulara cevap verebilen 123 ebeveyn ve çocukları araştırmamızın örneklemini oluşturmuştur. 


\section{|̧̇ıım}

Çalışmaya başlamadan önce İnönü Üniversitesi Sağlık Bilimleri Girişimsel Olmayan Klinik Araştırmalar Etik Kurulu'ndan (Karar no 2019/3-25) etik kurul izni ve araştırmanın yürütüldüğü okuldan kurum izni (Sayı: 2018/61316475-44-E.8045378) alınmıştır. Araştırmaya alınma kriterlerini sağlayan çocuk ve ebeveynlerine araşıımanın amacı açıklanarak araştırma hakkında genel bilgiler verilmiştir. Araştırmaya katımayı kabul eden çocuk ve ebeveynlerinden bilgilendirilmiş onam alınmıştır.

Veriler Google Form programı aracılığılla hazırlanan online anket formu ile Ocak - Mayıs 2020 0cak-Mart 2021 tarihleri arasında elde edilmiştir. Veri toplama öncesinde okul yönetimi, öğretmenler, çocuk ve ebeveynler araştırma hakkında bilgilendirilmiştir. Araştırmaya katılmayı kabul eden çocuk ve ebeveynlere araşıırmacılar tarafından online anket formu kısa mesaj yoluyla gönderilmiş̧tir. Araştırmaya katılan çocuk ve ebeveynlerden online ortamda aydınlatılmış onam alındıktan sonra veriler toplanmaya başlanmıştır. Anketin sonlanması için bir zaman kısıtlaması yapılmamıştır.

\section{Veri Toplama Araçları}

Verilerin toplanmasında 'Ebeveyn ve Çocuk Bilgi Formu', 'Çocuk Uyku Alışkanlıkları Anketi 've 'Çocuklar için Dijital Oyun Bağımlılı̆ı Ölçeği' kullanılmıştır.

\section{Ebeveyn ve Çocuk Bilgi Formu}

Araştırmacılar tarafından hazırlanan ebeveyn ve çocuk bilgi formu çocuk ve ebeveynlerin sosyodemografik özelliklerinin değerlendirilmesi amacıyla hazırlanmıştır. Bu form yaş, cinsiyet, sosyoekonomik durum, evde bilgisayar olma durumu, çocukların bilgisayarda harcadıklar zaman vs sosyodemografik özellikleri içeren 13 sorudan oluşmaktadır.

\section{Çocuk Uyku Alışkanlıkları Anketi}

Owens ve arkadaşlarının 2000 ylında çocukların uyku alışkanlıklarını ve uyku bozukluklarını incelemeye yönelik olarak geliştirmiş oldukları ölçek 33 maddeden oluşmaktadır. Ölçeğin yatma zamanı direnci, gün içinde uykululuk, parasomnia, uykuya dalmanın gecikmesi, uyku süresi, uyku kaygısı, gece uyanmalar ve uykuda solunumun bozulması olmak üzere sekiz alt boyutu bulunmaktadır. Ölçekte, anne-babalardan çocuklarının uyku alışkanlıklarını ve sorunlarını bir önceki hafta üzerinden değerlendirmeleri istenmektedir. Toplamda elde edilen 41 puan kesim noktası olarak kabul edilmekte ve bunun üzerindeki değerler 'klinik düzeyde anlamlı' olarak değerlendirilmektedir. Ölçeğin Türkçe geçerlilik ve güvenirliliği Perdahlı Fiş ve ark. tarafından 2010 yılında yapıımış ve Cronbach alfa katsayısı 0.78 olarak belirlenmiştir (22). Araştırmamız için ölçeğin Cronbach alfa iç tutarlık katsayısı 0.70 bulunmuştur.

\section{Çocuklar İ̧in Dijital Oyun Bağımlllı̆ı̆ Ölçeği}

Hazar tarafından 2016 ylında geliştirilen bu ölçek 24 maddeden oluşmaktadır. Ölçeğin dijital oyun oynamaya yönelik aşırı odaklanma ve çatışma, oyun sürecinde tolerans gelişimi ve oyuna yüklenen değer, bireysel ve sosyal görevlerin/ödevlerin ertelenmesi, yoksunluğun psikolojik-fizyolojik yansıması ve oyuna dalma şeklinde 4 alt boyutu bulunmaktadır. Araştırmamız için ölçeğin Croanbach Alpha iç tutarlık katsayısı .93 bulunmuştur.

\section{Veri Analizi}

Araştırma sonucunda elde edilen verilerin değerlendirilmesi SPSS (Statistical Package For Social Sciences) 25.0 paket programı ile elektronik ortamda yapılmıştır. Tanımlayıcı istatistikler için yüzdelik dağılım ve ortalama kullanılmışıı. Çocukların bazı değişkenlere göre dijital oyun bağımlılık düzeylerini karşılaştırmak için karşılaştırmalı istatistiklerden bağımsız gruplarda t testi, değişkenler arasında ilişkiyi belirlemek için ise Pearson korelasyon analizi kullanılmıştır. İstatistiksel anlamlılık için p değeri 0.05 olarak belirlenmiştir. 


\section{Bulgular}

Araştırmamıza katılan çocukların \%52'sinin kız, yaş ortalamalarının $10.21 \pm 1.30$ ve akademik başarılarının çoğunlukla iyi olduğu belirlenmiştir. Çocukların \%84.6'sının evinde bilgisayar/tablet bulunduğu, çocukların \%96.7'sinin bilgisayarda/tablette vakit geçirdiği, \%88.6'sının bilgisayar/tablette vakit geçirmelerine izin verildiği, bilgisayar /tableti günlük kullanma süreleri ortalamasının $3.58 \pm 2.61$ saat olduğu, \%36.6'sının oyun oynamak için bilgisayar/ tableti kullandığı ve \%92 'sinin dijital oyun bağımlılı̆ı için riskli grupta olduğu bulunmuştur (Tablo 1). Ayrıca çocukların ortalama uyku sürelerinin $11.24 \pm 6.90$ saat olduğu ve tamamının uyku sorunu yaşadığı belirlenmiştir.

\section{Tablo 1. Çocukların sosyo demografik özellikleri}

\begin{tabular}{|c|c|c|c|}
\hline & & $\mathrm{N}$ & $\%$ \\
\hline \multirow{2}{*}{ Cinsiyet } & KIZ & 64 & 52 \\
\hline & Erkek & 59 & 48 \\
\hline \multirow[t]{2}{*}{ Evde bilgisayar/tablet bulunma durumu } & Evet & 104 & 84.6 \\
\hline & Hayır & 19 & 15.4 \\
\hline \multirow[t]{2}{*}{ Bilgisayar/tablette vakit geçirme durumu } & Evet & 119 & 96.7 \\
\hline & Hayır & 4 & 3.3 \\
\hline \multirow[t]{2}{*}{$\begin{array}{l}\text { Bilgisayar/tablette vakit geçirmesine izin verilme } \\
\text { durumu }\end{array}$} & Evet & 109 & 88.6 \\
\hline & Hayır & 14 & 11.4 \\
\hline \multirow[t]{5}{*}{ Bilgisayar/tableti kullanma amacı } & Ders çalışmak & 16 & 13 \\
\hline & Oyun oynamak & 45 & 36.6 \\
\hline & Facebook/instagram & 6 & 4.9 \\
\hline & Ders çalışmak ve oyun oynamak & 45 & 36.6 \\
\hline & Diğer & 10 & 8.1 \\
\hline \multirow[t]{6}{*}{ Çocuğun akademik başarısı } & Zaylf & 2 & 1.6 \\
\hline & Geçer & 1 & .8 \\
\hline & Orta & 17 & 13.8 \\
\hline & Iyi & 50 & 40.7 \\
\hline & Pekiyi & 53 & 43.1 \\
\hline & \multicolumn{3}{|l|}{ Mean $\pm S d$} \\
\hline Yaş ortalaması & \multicolumn{3}{|l|}{$10.21 \pm 1.30$} \\
\hline Bilgisayar /tablet kullanma süresi & \multicolumn{3}{|l|}{$3.58 \pm 2.61$} \\
\hline Uyku süresi & \multicolumn{3}{|l|}{$11.24 \pm 6.90$} \\
\hline
\end{tabular}

Tablo 2. Çocukların bazı demografik özellikleri ile uyku ölçeğinin alt boyutlarının karşılaşıııııası

\begin{tabular}{|c|c|c|c|c|c|c|c|c|c|c|}
\hline & & $\begin{array}{l}\text { Yatma } \\
\text { zamanı } \\
\text { direnci }\end{array}$ & $\begin{array}{c}\text { Uykuya } \\
\text { dalmanın } \\
\text { gecikmesi }\end{array}$ & Uyku süresi & $\begin{array}{l}\text { Uyku } \\
\text { kaygısı }\end{array}$ & $\begin{array}{c}\text { Gece } \\
\text { uyanmalan }\end{array}$ & Parasomnia & $\begin{array}{c}\text { Uykuda } \\
\text { solunum } \\
\text { bozulması }\end{array}$ & $\begin{array}{l}\text { Gūn içinde } \\
\text { uykululuk }\end{array}$ & Uyku toplam \\
\hline \multirow{4}{*}{$\begin{array}{l}\text { Evde } \\
\text { bilgisayar/tablet } \\
\text { bulunma durumu }\end{array}$} & Evet & $10.95 \pm 1.91$ & $2.74 \pm .052$ & $7.00 \pm .084$ & $6.35 \pm 2.15$ & $3.80 \pm 1.19$ & $8.64 \pm 1.85$ & $3.49 \pm 1.16$ & $12.92 \pm 2.34$ & $52.67 \pm 6.01$ \\
\hline & Hayır & $10.68 \pm 1.60$ & $2.57 \pm .69$ & $6.733 \pm 1.14$ & $5.89 \pm 1.88$ & $3.63 \pm .076$ & $8.36 \pm 1.30$ & $3.36 \pm .076$ & $12.52 \pm 1.77$ & $50.94 \pm 4.47$ \\
\hline & $t$ & 1.059 & 4.311 & 3.839 & 1.46 & 1.176 & 3.162 & .774 & 1.377 & .608 \\
\hline & $p$ & .306 & .040 & .052 & .228 & .280 & .078 & .381 & .243 & .437 \\
\hline \multirow{4}{*}{$\begin{array}{l}\text { Çocuğun } \\
\text { bilgisayar/tablette } \\
\text { zaman geçirme } \\
\text { durumu }\end{array}$} & Evet & $10.87 \pm 1.84$ & $2.70 \pm .55$ & $6.94 \pm 088$ & $6.28 \pm 2.09$ & $3.78 \pm 1.14$ & $8.64 \pm 1.78$ & $3.48 \pm 1.12$ & $12.84 \pm 2.26$ & $52.39 \pm 5.82$ \\
\hline & Hayır & $12.0 \pm 2.44$ & $3.00 \pm .000$ & $7.75 \pm .095$ & $6.25 \pm 2.87$ & $3.50 \pm 1.00$ & $7.25 \pm 050$ & $3.00 \pm .000$ & $13.50 \pm 2.38$ & $52.75 \pm 6.75$ \\
\hline & $t$ & .916 & 7.046 & .415 & .722 & .049 & 4.89 & 3.237 & .001 & .569 \\
\hline & $p$ & .340 & .009 & .521 & .397 & .825 & .029 & .074 & .981 & .452 \\
\hline \multirow{4}{*}{$\begin{array}{l}\text { Bilgisayar/tablette } \\
\text { vakit geçirmesine } \\
\text { izin verilme } \\
\text { durumu }\end{array}$} & Evet & $10.87 \pm 1.88$ & $2.72 \pm .054$ & $7.02 \pm .081$ & $6.24 \pm 2.06$ & $3.71 \pm 1.02$ & $8.55 \pm 1.75$ & $3.50 \pm 1.15$ & $12.71 \pm 2.16$ & $52.22 \pm 5.21$ \\
\hline & Hayır & $11.21 \pm 1.76$ & $2.64 \pm .063$ & $6.50 \pm 1.34$ & $6.57 \pm 2.50$ & $4.28 \pm 1.72$ & $8.92 \pm 1.97$ & $3.21 \pm .057$ & $14.00 \pm 2.80$ & $53.85 \pm 7.96$ \\
\hline & $\mathrm{t}$ & .072 & .810 & 7.54 & 1.179 & 5.435 & .500 & 3.091 & .144 & 1.011 \\
\hline & $p$ & .788 & .370 & .007 & .280 & .021 & .481 & .081 & .705 & .317 \\
\hline
\end{tabular}

Bazı demografik özelliklere göre uyku ölçeği ve alt boyutları karşlaştıııımışır. Evde bilgisayar/tablet bulunma durumları ile uykuya dalmanın gecikmesi alt boyutunun puanları arasında fark olduğu belirlenmiştir $(p<0.05)$. Çocukların bilgisayar / tablette zaman geçirme durumları ile uykuya dalmanın gecikmesi ve parasomnia alt boyutlarının puanları arasında fark olduğu tespit edilmiş̧ir $(p<0.05)$. Ayrıca 
çocukların bilgisayar/tablette vakit geçirmelerine izin verilmesi durumları ile uyku süresi ve gece uyanma alt boyutlarının puanları arasında fark olduğu bulunmuştur ( $\mathrm{p}<0.05$ ). (Tablo 2).

Tablo 3. Uyku ve dijital oyun bağımlılığı ölçeği ile çocukların bilgisayar/tableti kullanma süresi ve akademik başarıları arasındaki ilişki

\begin{tabular}{|c|c|c|c|}
\hline & & $\begin{array}{l}\text { Bilgisayar/tableti günlük } \\
\text { kullanma süresi }\end{array}$ & $\begin{array}{l}\text { Çocuğun akademik } \\
\text { başarısı }\end{array}$ \\
\hline \multirow[t]{2}{*}{ Uyku Süresi } & $r$ & -.043 & $.217^{*}$ \\
\hline & $p$ & .713 & .016 \\
\hline \multirow[t]{2}{*}{ Uyku kaygısı } & $r$ & $.245^{*}$ & -.157 \\
\hline & $p$ & .034 & .082 \\
\hline \multirow[t]{2}{*}{ Gece uyanmaları } & $r$ & $.287^{*}$ & -.137 \\
\hline & $p$ & .013 & .132 \\
\hline \multirow[t]{2}{*}{ Parasomnia } & $r$ & $.466^{*+}$ & -.104 \\
\hline & $p$ & .000 & .254 \\
\hline \multirow[t]{2}{*}{ Gün içinde uykululuk } & r & .042 & $-.178^{*}$ \\
\hline & $p$ & .720 & .049 \\
\hline \multirow[t]{2}{*}{ Uyku Toplam } & $r$ & $.289^{*}$ & -.117 \\
\hline & $p$ & 0.12 & .119 \\
\hline \multirow{2}{*}{$\begin{array}{l}\text { Yoksunluğun psikolojik-fizyolojik } \\
\text { yansıması ve oyuna dalma }\end{array}$} & $r$ & $.268^{*}$ & $-.325^{* *}$ \\
\hline & $p$ & .020 & .000 \\
\hline \multirow{2}{*}{$\begin{array}{l}\text { Bireysel ve sosyal } \\
\text { görevlerin/ödevlerin ertelenmesi }\end{array}$} & $r$ & $.346^{* *}$ & $-.314^{* * *}$ \\
\hline & $p$ & .002 & .000 \\
\hline \multirow{2}{*}{$\begin{array}{l}\text { Oyun sürecinde tolerans gelişimi } \\
\text { ve oyuna yüklenen değer }\end{array}$} & $r$ & $.346^{* *}$ & -.162 \\
\hline & $p$ & .002 & .073 \\
\hline \multirow{2}{*}{$\begin{array}{l}\text { Dijital oyun oynamaya yönelik } \\
\text { aşırı odaklanma ve çatışma }\end{array}$} & $r$ & $432^{* *}$ & $-.221^{*}$ \\
\hline & $p$ & 000 & .014 \\
\hline \multirow[t]{2}{*}{ Oyun Toplam } & $r$ & $384^{* *}$ & $-.271^{* *}$ \\
\hline & $p$ & 001 & .002 \\
\hline
\end{tabular}

Tablo 4. Dijital oyun bağımlılığı ölçeği ve uyku ölçeği arasındaki ilişki

\begin{tabular}{|c|c|c|c|c|c|c|}
\hline & & Uyku kaygısı & $\begin{array}{l}\text { Gece } \\
\text { uyanmaları }\end{array}$ & Parasomni & $\begin{array}{l}\text { Gün içinde } \\
\text { uykululuk }\end{array}$ & $\begin{array}{l}\text { Uyku } \\
\text { Toplam }\end{array}$ \\
\hline \multirow{2}{*}{$\begin{array}{l}\text { Yoksunluğun } \\
\text { psikolojik-fizyolojik } \\
\text { yansıması ve oyuna } \\
\text { dalma }\end{array}$} & $r$ & $.203^{*}$ & .150 & $.177^{*}$ & $.202^{*}$ & $.244^{* *}$ \\
\hline & $p$ & .025 & .098 & .050 & .025 & .006 \\
\hline \multirow{2}{*}{$\begin{array}{l}\text { Bireysel ve sosyal } \\
\text { görevlerin/ödevlerin } \\
\text { ertelenmesi }\end{array}$} & $r$ & .080 & $.186^{*}$ & .168 & .132 & $.182^{*}$ \\
\hline & $p$ & .379 & .039 & .063 & .145 & .044 \\
\hline \multirow{2}{*}{$\begin{array}{l}\text { Oyun sürecinde } \\
\text { tolerans gelişimi ve } \\
\text { oyuna yüklenen } \\
\text { değer }\end{array}$} & $r$ & $.192^{*}$ & $.195^{*}$ & $.262^{\text {t* }}$ & .155 & $.262^{* *}$ \\
\hline & $p$ & .034 & .031 & .003 & .087 & .003 \\
\hline \multirow{2}{*}{$\begin{array}{l}\text { Dijital oyun } \\
\text { oynamaya yönelik } \\
\text { aşırı odaklanma ve } \\
\text { çatışma }\end{array}$} & $r$ & $.233^{* *}$ & $.262^{* *}$ & $.243^{* *}$ & .156 & $.311^{* *}$ \\
\hline & $p$ & .010 & 003 & .007 & .085 & .000 \\
\hline \multirow[t]{2}{*}{ Oyun Toplam } & $r$ & $.194^{*}$ & $.227^{*}$ & $.235^{\star \star}$ & .174 & $.281^{* *}$ \\
\hline & $p$ & .031 & .011 & .009 & .054 & .002 \\
\hline
\end{tabular}


Uyku ve dijital oyun bağımlılı̆ı ölçeği ile çocukların bilgisayar/tableti kullanma süresi ve akademik başarıları arasındaki ilişki incelenmiştir. Çocukların bilgisayar/tableti günlük kullanma süreleri ile uyku kaygısı, gece uyanma, parasomnia, uyku toplam puanı, dijital oyun bağımlı̆ı̆ı toplam puanı ve tüm alt boyutları arasında pozitif ilişki olduğu belirlenmiştir. Çocukların akademik başarıları ile uyku süresi arasında pozitif ilişki, gün içinde uykululuk, yoksunluğun psikolojik-fizyolojik yansıması ve oyuna dalma, bireysel ve sosyal görevlerin/ödevlerin ertelenmesi, dijital oyun oynamaya yönelik aşırı odaklanma ve çatışma, dijital oyun bağımlıı̆̆ ölçeğinin toplam puanı arasında negatif ilişsi olduğu tespit edilmiştir (Tablo 3). Aynı zamanda araşıırmamızda dijital oyun bağımlılı̆ı ölçeği ve alt boyutlarının uyku kaygısı, gece uyanmaları, parasomnia, gün içinde uykululuk ve uyku ölçeği toplam puanlarını pozitif yönde etkilediği belirlenmiştir (Tablo 4).

\section{Tartışma}

Son bir yılda yaşadığımız pandemi ile beraber çocuklar, evde kaldıkları bu süreçte gerek eğitim faaliyetlerini sürdürmek gerekse sosyalleşmek ve eğlenmek için dijital araçları kullanmaya başlamışlardır $(23,24)$. Ancak teknoloji kullanımlarının erken çocukluk dönemlerinden itibaren başlaması ve ebeveynler tarafından denetlenmemesi gibi durumlar çocuklarda kontrolsüz teknoloji kullanımlarına ve digital oyun bağımlılı̆ı düzeylerinin artmasına neden olabilmektedir (35). Araştırmamızın bulguları değerlendirildiğinde çocukların bilgisayar/ tablette günlük ortalama 3.5 saat vakit geçirdikleri ve dijital oyun bağımlılı̆ı için riskli grupta oldukları belirlenmiştir. İlgili alanda pandemide çocukların yoğun bir şekilde digital ortamlarda vakit geçirdiği ve son yıllarda oyun bağımlılıklarının kaygı verici boyutta olduğu görülmektedir (35). Erol (2020) salgın sürecinde çocuk ve ergenlerin ekran başında daha fazla zaman geçirdikleri ve yeni çevrimiçi gruplara dahil olma durumlarının arttığını ifade etmisştir(20). Yektaş (2020) pandemi sürecinde ergenler arasında ekran maruziyetinin ve internet kullanım yoğunluğunun artı̆ğını belirtmiştir (24). Pandemi sürecinde çocukların ekran maruziyetlerinin belirli saatlere indirgenmesi ve eğitim faaliyetleri dışındaki teknoloji kullanımlarının ebeveynlerin gözetiminde olmasının, çocukların oyun bağımlı̆̆g riskinin azaltılmasında önemli olabileceği düşünülebilir.

Çalışmamızda çocukların çoğunlukla akademik başarılarııın iyi olduğu ancak dijital oyun bağımlıık durumlarının akademik başarılarını negatif yönde etkilediği saptanmıştır. Literatürde dijital oyun bağımlılığının birçok sağlık sorununa neden olabileceği (3) ve oyun bağımlılık düzeyleri yüksek olan çocukların akademik başarılarının düşük olduğu belirlenmiştir (14). Ayrıca bazı çalışmalarda da pandemi sürecinde çocukların çeşitli stres faktörlerine maruz kalması, uzaktan eğitimle eğitim faaliyetlerinin sürdürülmesi gibi durumların çocukların akademik başarılarını olumsuz yönde etkilediği ifade edilmiştir $(20,23,24)$. Çocukların dijital ortamlarda uzun süre vakit geçirmesinin, eğitim faaliyetlerini sürdürmesinde aksamalara neden olabileceği ve bu durumun akademik başarılarını olumsuz yönde etkileyebileceği söylenebilir. Bu nedenle çocukların digital oyun bağımlııkları ile akademik başarılarının incelenmesine yönelik çalışmaların yapıımasının önemli olacağı düşünülmektedir.

Çocukların sağlıkı büyüme ve gelişmeleri için önemli yaşam aktivitelerinden biri olan uyku birçok fizyolojik, psikolojik ve çevresel faktörler etkilenebilmektedir $(25,26)$. Konu ile ilgili olarak bazı çalışmalarda pandemi sürecinde çocuklarda gün ışığına maruziyette ve fiziksel aktivitede azalma, sağlık kaygısı, gelecekle ilgili belirsizlik yaşamaya bağlı stres düzeylerinde artma, uzun süreli ekrana maruz kalma gibi durumların çocukların uykularını etkileyebileceği bildirilmiştir $(27,28)$. Benzer şekilde Covid-19 nedeniyle evde kalmanın tüm yaş gruplarındaki çocukların uyku alışkanlıklarını bozabileceğini, çocukların uyku/uyanıklık süreçlerinin olumsuz etkilendiğini ve çocukların uyku sorunlarında artış olduğu ifade edilmiştir $(29,30)$. Araştırmamızda da tüm çocukların uyku sorunu yaşadığı belirlenmiş olup bu bulgu literatürle benzerlik göstermiştir. Çalışmamıza katılan tüm çocukların uyku süreçlerinin yaşadığımız bu salgın sürecinden olumsuz etkilenmesi önemli bir bulgudur. Pandemide çocukların yaşadıkları stres, kaygıyla beraber ekran maruziyetinde artma gibi durumların çocuklarda uyku sorunlarına neden olabildiği söylenebilir. 
Çalışmamızda dijital oyun bağımlıı̆ı ölçeği ve alt boyutlarının uyku kaygısı, gece uyanmaları, parasomnia, gün içinde uykululuk ve uyku ölçeği toplam puanlarını pozitif yönde etkilediği belirlenmiştir. İlgili alanda dijital teknoloji kullanımının çocuklarda uyku sorunlarına neden olabileceğine dair kanılların giderek arttığı görülmektedir $(31,32)$. Yapılan çalısmalarda çocukların uzun süreli teknoloji kullanımlarının ve digital oyun oynamalarının çocukların uyku kalitesini olumsuz yönde etkileyebileceği ve önemli uyku bozukluklarına neden olabileceği belirtilmiştir $(27,33,34)$. Teknoloji kullanımının çocuklarda fiziksel, bilişsel ve duygusal değişimlerle birlikte uyku sorunlarına yol açabileceği görülmektedir. Çocukların uyku saatlerinde oyun oynama, oyun oynarken uzun süre parlak ışığa maruz kalma ve duygusal olarak etkilenme durumlarının uyku alışkanlıklarını etkileyebileceği söylenebilir.

Araştırmamızın sınırlıığını çalışmamızın benzer kültürel özellik taşıması amacıyla bir bölgedeki tek bir okulda yapılmasıdır. Ancak geniş çaplı araştırmalarla tüm il genelinde yapılması önemli olabilir. Çocukların pandemi sürecinde dijital bağımlıık düzeyleri ile bu süreçteki uyku alışkanlıklarının beraber ele alınması çalışmamızın güçlü yönüdür.

Sonuç olarak araştırmamızda çocukların dijital oyun bağımılığı için riskli grupta oldukları ve uyku sorunu yaşadıkları belirlenmiştir. Aynı zamanda çocukların oyun bağımlı̆̆ı düzeylerinin, uykularını ve akademik başarılarını etkileyebileceği saptanmıştır. Covid-19 salgını sırasında çocukların akademik başarılarını destekleyecek farkı eğitim ve öğrenme modellerinin kullanılmasının yanı sıra teknoloji kullanım sürelerine özen gösterilmesi, bağımlıık davranışı gösterecek kadar kullanımların önüne geçilmesi ve teknoloji kullanımları ile uykularını etkileyebilecek risk faktörlerinin değerlendirilmesi önemlidir. Bu doğrultuda sağlık profesyonellerinin çocukların uyku alışkanlıklarını etkileyebilecek olumsuz faktörleri belirlemesi ve uyku sorunu yaşayan çocuklara gerekli tedavi ve bakımı sağlaması gerektiği düşünülmektedir. Ayrıca çocukların teknoloji kullanımları ile uyku gereksinimlerine göre eğitim ve danışmanlık verilmesi önerilmektedir.

\section{Kaynaklar}

1. Aydoğdu F. Digital oyun oynayan çocukların digital oyun bağımlılıklarının çeşitli değişkenler açısından incelenmesi. Ulakbilge Dergisi 2018; 6(31): 1-18.

2. Küçük Y, Çakır R. Ortaokul öğrencilerinin dijital oyun bağımlılıklarının çeşitli değişkenler açıından incelenmesi. Turkish Journal of Primary Education 2020; 5(2): 133-54.

3. Göldağ B. Lise öğrencilerinin dijital oyun bağımlılık düzeylerinin demografik özelliklerine göre incelenmesi. Yüzüncü Yıl Üniversitesi Eğitim Fakültesi Dergisi 2018; 15(1): 1287-1315.

4. Taş İ, Sevinç H. Çocuklarda aleksitimi, bilgisayar oyun bağımlılı̆ı ve empatik eğilim arasındaki ilişki: bir yapısal eşitlik modellemesi. Ayna Klinik Psikoloji Dergisi 2019; 6(3): 271-288.

5. Yalçın Irmak A, Erdoğan S. Ortaokul öğrencilerinin dijital oyun bağımlılıklarının çeşitli değişkenler açısından incelenmesi. Turk Psikiyatri Derg 2016; 27(2): 128-137.

6. Gentile DA, Choo H, Liau A, et al. Pathological video game use among youths: A two-year longitudinal study. Pediatrics 2011; 127(2): 319-329.

7. Aksel N, Sarı E. Ortaokul öğrencilerinin dijital oyun bağımlılığı, öz denetimi ve sosyal eğilimleri. Ordu Üniversitesi Sosyal Bilimler Araştırmaları Dergisi 2020; 10(2): 436-444.

8. Hazar Z, Hazar K, Gökyürek B, et al. Ortaokul öğrencilerinin oyunsallık, dijital oyun bağımlılığı ve saldırganlık düzeyleri arasındaki ilişkinin çeşitli değişkenler açısından incelenmesi. Journal of Human Sciences 2017; 14(4): 4320-4332.

9. Hazar Z, Hazar M. Çocuklar için dijital oyun bağımlıı̆ı ölçeği. Journal of Human Sciences 2017; 14(1): 203216.

10. Green SC, Bavelier D. Action video game modifies visual selective attention. Nature 2003; 423: 534-537.

11. Tüzün Ü. Gelişen iletişim araçlarının çocuk ve gençlerin etkileşimi üzerine etkisi. Dusunen Adam 2002; 15(1): 46-50.

12. Şahin C, Tuğrul VM. İlköğretim öğrencilerinin bilgisayar oyunu bağımlılık düzeylerinin incelenmesi. Journal of World of Turks 2012; 4(3): 115-130.

13. KIıç KM. Ergenlerde dijital oyun bağımlıı̆ı, zorbalık bilişleri ve empati düzeyleri arasındaki ilişkiler. Elementary Education Online 2019; 18(2): 549-62. 
14. Öztürk Eyimaya $A$, Uğur $S$, Sezer TA, Tezel A. İlkokul dördüncü sınıf öğrencilerinde dijital oyun bağımlılığının uyku ve diğer bazı değişkenlere göre incelenmesi. Journal of Turkish Sleep Medicine 2020; 7(2): 283-290.

15. Akçay D. Ebeveynlerin çocukların dijital video oyunları bağımlıı̆̆ı karşısında tutum ve davranışları. Middle Black Sea Journal of Communication Studies 2020; 5(2): 65-71.

16. Balcı $E$, Durmuş $H$, Sezer L. Corona günlerinde uzaktan eğitim bağımlılık gelişiminde bir risk oluşturur mu? Bağımlılık Dergisi 2021; 22(1): 100-102.

17. Majeed M, Irshad M, Fatima T, et al. Relationship between problematic social media usage and employee depression: a moderated mediation model of mindfulness and fear of COVID-19. Front Psychol 2020; 11: 557987.

18. Király 0, Potenza MN, Stein DJ, et al. Preventing problematic internet use during the COVID-19 pandemic: Consensus guidance. Compr Psychiatry 2020; 100: $152180 .$.

19. Gökler ME, Turan Ş. Covid-19 pandemisi sürecinde problemlï teknolojī kullanımı. Estüdam Halk Sağlığı Dergisi 2020; 5(2): 108-114.

20. Erol R. COVID-19 Enfeksiyonunun çocuklar üzerindeki psikososyal etkileri. Yüksek intisas Üniversitesi Sağllk Bilimleri Dergisi 2020; 1(3): 109-114.

21. Aktaş B, Bostancı Daştan N. Covid-19 pandemisinde üniversite öğrencilerindeki oyun bağımllığı düzeyleri ve pandeminin dijital oyun oynama durumlarına etkisi. Bağımlıık Dergisi 2021; 22(2): 129-138.

22. Perdahlı Fiş $\mathrm{N}$, Arman $\mathrm{A}, \mathrm{Ay} \mathrm{P}$, et al. Çocuk uyku alışkanlıkları anketinin türkçe geçerliliği ve güvenilirliği. Anadolu Psikiyatri Derg 2010;11(2): 151-160.

23. Erol M, Erol A. Koronavirüs pandemisi sürecinde ebeveynlerĩ gözünden ilkokul öğrencīerì. Milli Eğitim Dergisi 2020; 49(1): 529-551.

24. Yektaş Ç. Ergenlerde pandeminin ruhsal etkileri. Türkiye Klinikleri Dergisi 2020; (1): 13-18.

25. Öztürk A, Sezer TA, Tezel A. Ilkkokul öğrencilerinin uyku ve televizyon izleme alışkanlıklarının değerlendirilmesi. Journal of Turkish Sleep Medicine 2018; 5 (3): 73-80.

26. Mastin DF, Bryson J, Corwyn R. Assessment of sleep hygiene using the sleep hygiene index. J Behav Med 2006; 29(3): 223-227.

27. Bruni 0 , Sette $S$, Fontanesi $\mathrm{L}$, et al. Technology use and sleep quality in preadolescence and adolescence. J Clin Sleep Med 2015; 11(12): 1433-1441.

28. Becker SP, Gregory AM. Editorial Perspective: Perils and promise for child and adolescent sleep and associated psychopathology during the COVID-19 pandemic. J Child Psychol Psychiatry 2020; 61(7): 757-759.

29. Bruni 0 , Malorgio $\mathrm{E}$, Doria $\mathrm{M}$, et al. Changes in sleep patterns and disturbances in children and adolescents in Italy during the Covid-19 outbreak. Sleep Med 2021; doi: 10.1016/j.sleep.2021.02.003.

30. Ghosh R, Dubey MJ, Chatterjee S, Dubey S. Impact of COVID-19 on children: Special focus on the psychosocial aspect. Minerva Pediatr 2020; 72(3): 226-235.

31. Hysing M, Pallesen S, Stormark KM, et al. Sleep and use of electronic devices in adolescence: Results from a large population-based study. BMJ Open 2015; 5(1): e006748.

32. Mustafaoğlu R, Zirek E, Yasacı Z, Razak Özdinçler A. Digital teknoloji kullanımının çocukların gelişimi ve sağlığı üzerine olumsuz etkileri. Addicta: The Turkish Journal on Addictions 2018; 5(2): 1-21.

33. King DL, Gradisar M, Drummond A, L et al. The impact of prolonged violent video-gaming on adolescent sleep: An experimental study. J Sleep Res 2013; 22(2): 137-143.

34. Arora T, Broglia E, Thomas GN, Taheri S. Associations between specific technologies and adolescent sleep quantity, sleep quality and parasomnias. Sleep Med 2014; 15(2): 240-247.

35. Keya FD, Rahman MM, Nur MT, Pasa MK. Parenting and child's (five years to eighteen years) digital game addiction: A qualitative study in North-Western part of Bangladesh. Computers in Human Behavior Reports 2020; 2: 100031. 